\title{
PENGARUH PERSEPSI PENGUSAHA KECIL DAN MENENGAH TERHADAP PENGGUNAAN SAK ETAP DI KOTA BANDAR LAMPUNG
}

(Studi Pada Sentra Kripik Segalamider Bandar Lampung)

\author{
Rosmiaty tarmizi \\ Ni Luh Sartika Bugawanti \\ (Universitas Bandar Lampung) \\ E-mail: rosmiati.tarmizi@yahoo.com
}

\begin{abstract}
Accounting practices, financial accounting in particular on SMEs in Indonesia is still low and has many drawbacks. Weakness, partly due to lack of education, lack of understanding of Financial Accounting Standards (GAAP) of the owners and managers in the absence of regulations requiring the preparation of financial statements for SMEs. The main problem in this research is how the influence of perception of small and medium enterprises to the use of SAK ETAP?.

The purpose of this study was to determine the effect of the perception of how small and medium enterprises to the use of SAK ETAP ". The hypothesis is the perception of small and medium enterprises to the use of SAK ETAP in Bandar Lampung. From the discussion of the results obtained by the regression equation $Y=$ $22.760+0.300 X$ and hypothesis test results using the t test, where the real level tcount $d f=54$ and $\alpha=0.05$ at 3.567 significant at $p$-value 0.001 and the value of TTable (appendix t_tabel ) of 2.005, thus tcount> TTable (3.567> 2.005). Which means that the hypothesis is proven and can be accepted as true.
\end{abstract}

Keywords: Perception, Small and Medium Enterprises, SAK ETAP

\section{LATAR BELAKANG}

Perkembangan sektor UKM yang demikian pesat memperlihatkan bahwa terdapat potensi yang besar jika hal ini dapat dikelola dan dikembangkan dengan baik yang tentunya akan dapat mewujudkan usaha menengah yang tangguh. Sementara itu, di sisi yang lain UKM juga masih dihadapkan pada masalah yang terletak pada proses administrasi. Masalah utama dalam pengembangan UKM yaitu mengenai pengelolaan keuangan dalam usahanya tersebut, karena pengelolaan yang baik memerlukan keterampilan akuntansi yang baik pula oleh pelaku bisnis UKM. Pemerintah sudah mencoba membantu mengatasi kendala yang dihadapi oleh sebagian besar UKM, seperti melakukan pembinaan dan pemberian kredit lunak. Selain itu, apabila UKM berkeinginan memperoleh tambahan modal juga dituntut menyertakan laporan keuangan sebagai syarat mengajukan pinjaman kepada pihak bank. Pihak perbankan sendiri tidak ingin mengambil resiko dalam penyaluran kredit bagi UKM dikarenakan perbankan 
tidak mengetahui perkembangan usaha tersebut. Sementara hampir semua UKM tidak memiliki laporan kinerja usaha dan keuangan yang baik sebagai syarat untuk memperoleh kredit. Hal ini terjadi karena UKM tidak dibiasakan untuk melakukan pencatatan dan penyusunan laporan keuangan sebagai gambaran kegiatan usaha dan posisi keuangan perusahaan. Padahal dengan adanya laporan keuangan akan memungkinkan pemilik memperoleh data dan informasi yang tersusun secara sistematis. Laporan keuangan berguna bagi pemilik untuk dapat memperhitungkan keuntungan yang diperoleh, mengetahui berapa tambahan modal yang dicapai dan juga dapat mengetahui bagaimana keseimbangan hak dan kewajiban yang dimiliki sehingga setiap keputusan yang diambil oleh pemilik dalam mengembangkan usahanya akan didasarkan pada kondisi konkret keuangan yang dilaporkan secara lengkap bukan hanya didasarkan pada asumsi semata.

Kebanyakan dari UKM hanya mencatat jumlah uang yang diterima dan dikeluarkan, jumlah barang yang dibeli dan dijual, dan jumlah piutang/utang. Namun, pencatatan itu hanya sebatas pengingat saja dan tidak dengan format yang diinginkan oleh pihak perbankan. Meskipun tidak dapat dipungkiri mereka dapat mengetahui jumlah modal akhir mereka setiap tahun yang hampir sama jumlahnya jika kita mencatat dengan sistem akuntansi (H. Jati, Beatus B., Otniel N., 2004). Akuntansi merupakan indikator kunci kinerja usaha, informasi akuntansi berguna bagi pengambilan keputusan sehingga dapat meningkatkan pengelolaan perusahaan. Hal ini memungkinkan para pelaku UKM dapat mengidentifikasi dan memprediksi area-area permasalahan yang mungkin timbul, kemudian mengambil tindakan koreksi tepat waktu. Para pelaku UKM tidak hanya dapat menghitung untung atau rugi, tetapi yang terpenting untuk dapat memahami makna untung atau rugi bagi usahanya (Wulan dan Nindita, 2009).

Laporan keuangan yang merupakan bagian dari akuntansi menjadi salah satu komponen yang mutlak harus dimiliki oleh UKM jika mereka ingin mengembangkan usaha dengan mengajukan modal kepada para kreditur yang dalam hal ini adalah pihak perbankan. Untuk itu, kebiasaan untuk mencatat setiap kegiatan usaha yang terjadi dan menyusun laporan keuangan harus ditumbuhkan di kalangan UKM. 
Pemerintah Indonesia hingga saat ini belum mengatur secara khusus kewajiban UKM menyusun laporan keuangan. Namun demikian, Undang-Undang Republik Indonesia No. 40 Tahun 2007 tentang Perseroan Terbatas secara tidak langsung telah mengisyaratkannya melalui pasal 66 yang berbunyi "Direksi menyampaikan laporan tahunan kepada RUPS setelah ditelaah oleh Dewan Komisaris dalam jangka waktu paling lambat 6 (enam) bulan setelah tahun buku Perseroan berakhir. Laporan keuangan yang dimaksud disusun berdasarkan standar akuntansi keuangan. Dengan demikian, bagi suatu perusahaan yang berbadan hukum Perseroan Terbatas, tidak terkecuali usaha kecil ataupun menengah, diwajibkan menyusun laporan keuangan".

Praktek akuntansi, khususnya akuntansi keuangan pada UKM di Indonesia masih rendah dan memiliki banyak kelemahan (Wahdini \& Suhairi, 2006). Kelemahan itu, antara lain disebabkan rendahnya pendidikan, kurangnya pemahaman terhadap Standar Akuntansi Keuangan (SAK) dari manajer pemilik dan karena tidak adanya peraturan yang mewajibkan penyusunan laporan keuangan bagi UKM. Sudarini (1992) dalam Wahdini \& Suhairi (2006) juga membuktikan bahwa perusahaan kecil di Indonesia cenderung untuk memilih normal perhitungan (tanpa menyusun laporan keuangan) sebagai dasar perhitungan pajak. Karena, biaya yang dikeluarkan untuk menyusun laporan keuangan jauh lebih besar daripada kelebihan pajak yang harus dibayar.

Standar akuntansi keuangan yang dijadikan pedoman dalam penyusunan laporan keuangan harus diterapkan secara konsisten. Namun, karena UKM memiliki berbagai keterbatasan, kewajiban seperti itu diduga dapat menimbulkan biaya yang lebih besar bagi UKM dibandingkan dengan manfaat yang dapat dihasilkan dari adanya informasi akuntansi tersebut (cost-effectiveness). Di samping itu, tersedianya informasi yang lebih akurat melalui informasi akuntansi yang dihasilkan diduga tidak mempengaruhi keputusan atas masalah yang dihadapi manajemen (relevance).

Studi terhadap penerapan SAK memberikan bukti bahwa Standar Akuntansi yang dijadikan pedoman dalam penyusunan laporan keuangan overload (memberatkan) bagi UKM (Wahdini \& Suhairi, 2006). Dalam penelitian Wahdini dan Suhairi (2006) studi yang sama juga pernah dilakukan di beberapa negara, dan 
menyimpulkan bahwa Standar Akuntansi yang dijadikan pedoman dalam penyusunan laporan keuangan overload (memberatkan) bagi UKM (Williams, Chen, \& Tearney, 1989; Knutson \& Hendry, 1985; Nair \& Rittenberg 1983; Wishon 1985). Hal ini telah mendorong komite Standar Akuntansi Internasional (The International Accounting Standards Board) untuk menyusun Standar Akuntansi Keuangan yang khusus bagi UKM. Saat ini telah diterbitkan SAK baru khusus untuk ETAP (Entitas Tanpa Akuntabilitas Publik) dalam rangka pengembangan standar akuntansi bagi UKM.

Sekalipun memberatkan, penelitian tentang jenis informasi akuntansi yang disajikan dan digunakan oleh perusahaan kecil di Australia mengungkapkan bahwa informasi akuntansi utama yang banyak disiapkan dan digunakan perusahaan kecil adalah informasi yang diharuskan menurut undang-undang (statutory), yaitu Neraca, Laporan Laba Rugi, Laporan Perubahan Ekuitas, dan Laporan Arus Kas (Homes \& Nicholls, 1989). Dalam penelitian ini juga terungkap bahwa sebahagian besar UKM yang menjadi responden tidak mampu menyiapkan sendiri informasi akuntansi yang diperlukannya, sehingga perusahaan meminta jasa Akuntan Publik (Homes \& Nicholls, 1989).

Kondisi UKM di Kota Bandar Lampung, khususnya di sentra kripik Segalamider Kota Bandar Lampung juga tidak jauh berbeda, mereka masih banyak mengalami kesulitan dalam mempraktekan akuntansi sesuai ketentuan yang telah ditetapkan oleh Ikatan Akuntan Indonesia berdasarkan Standar Akuntansi Keuangan-Entitas Tanpa Akuntabilitas Publik (SAK-ETAP), sehingga informasi akuntansi yang dihasilkan tidak memadai dan juga tidak akurat.

\section{TINJAUAN PUSTAKA DAN HIPOTESIS}

\subsection{Pengertian Persepsi}

Menurut Kamus Besar Bahasa Indonesia (2008:674) persepsi diartikan sebagai tanggapan (penerimaan) langsung dari sesuatu atau merupakan proses seseorang mengetahui bebarapa hal melalui panca inderanya. 
Menurut Ikhsan dan Ishak (2005:57) persepsi adalah bagaimana orang melihat atau menginterpretasikan peristiwa, objek, serta manusia. Mangkunegara (dalam Arindita, 2000) berpendapat bahwa persepsi adalah proses pemberian arti atau makna terhadap lingkungan. Dalam hal ini persepsi mencangkup penafsiran obyek, penerimaan stimulis (input), pengorganisasian stimulus, dan pemberian penafsiran terhadap stimulus yang telah diorganisasikan dengan cara mempengaruhi prilaku dan perubahan sikap.

\subsection{Faktor Yang Mempengaruhi Persepsi}

Menurut Robbins (2003) persepsi pada umumnya dipengaruhi oleh dua faktor, yaitu faktor internal dan faktor ekstenal. Faktor internal berasal dari dalam diri individu misalnya sikap, kebiasaan dan kemauan. Sedangkan faktor eksternal adalah faktor yang berasal dari luar individu.

Dijelaskan oleh Robbins (2003) bahwa meskipun individu-individu memandang pada satu benda yang sama, mereka dapat mempersepsikannya berbeda. Hal ini dipengaruhi oleh:

1. Pelaku persepsi

Apabila seorang individu memandang suatu obyek dan mencoba menafsirkan apa yang dilihatnya, penafsiran itu sangat dipengaruhi oleh karakteristik pribadi dari pelaku persepsi individu itu, seperti sikap, motif, kepentingan, minat, pengalaman dan harapan.

2. Obyek atau yang dipersepsikan

Karakteristik dari target yang akan diamati dapat mempengaruhi apa yang dipersepsikan, sasaran itu mungkin berupa orang, benda atau peristiwa.

3. Keadaan dimana persepsi itu dilakukan.

Unsur lingkungan atau situasi yang terjadi saat seseorang menilai suatu obyek.

\subsection{Definisi Usaha Kecil dan Menengah}

Menurut Undang-Undang No 20 Tahun 2008 ini, yang disebut dengan usaha kecil adalah entitas yang memiliki kriteria sebagai berikut: 
1. Kekayaan bersih lebih dari $\mathrm{Rp} 50.000 .000,00$ (lima puluh juta rupiah) sampai dengan paling banyak Rp 500.000.000,00 (lima ratus juta rupiah) tidak termasuk tanah dan bangunan tempat usaha; dan

2. Memiliki hasil penjualan tahunan lebih dari $\mathrm{Rp} 300.000 .000,00$ (tiga ratus juta rupiah) sampai dengan paling banyak Rp 2.500.000.000,00 (dua milyar lima ratus juta rupiah).

Usaha Menengah adalah entitas usaha yang memiliki kriteria sebagai berikut:

1. Kekayaan bersih lebih dari $\mathrm{Rp} 500.000 .000,00$ (lima ratus juta rupiah) sampai dengan paling banyak Rp 10.000.000.000,00 (sepuluh milyar rupiah) tidak termasuk tanah dan bangunan tempat usaha; dan

2. Memiliki hasil penjualan tahunan lebih dari Rp2.500.000.000,00 (dua milyar lima ratus juta rupiah) sampai dengan paling banyak Rp 50.000.000.000,00 (lima puluh milyar rupiah).

\subsection{Peran dan Fungsi Usaha Kecil dan Menengah}

Menurut Suryana (2001:90-92) Fungsi dan peran Usaha Kecil dan Menengah sangat besar dalam kegiatan ekonomi masyarakat, meliputi:

1. Penyediaan barang dan jasa

2. Penyerapan tenaga kerja

3. Pemerataan pendapatan

4. Sebagai nilai tambah bagi produk daerah

5. Peningkatan taraf hidup masyarakat

Keberhasilan usaha kecil dan menengah dapat ditinjau dari dua sudut pandang, yaitu sudut pandang ekonomi dan sudut panang sosial. Dari segi ekonomi, keberhasilan perusahaan ditinjau dari adanya peningkatan kekayaan perusahaan diluar penjaman, misalnya kenaikan laba. Sedangkan dari segi social, keberhasilan perusahaan ditinjau dari adanya kelangsungan hidup perusahaan dengan kaitannya keberadaan perusahaan. 


\subsection{Standar Akuntansi Keuangan yang Berlaku di Indonesia}

Ikatan Akuntan Indonesia (IAI) hingga saat ini telah menerbitkan empat standar akuntansi di Indonesia atau yang biasa disebut empat pilar standar akuntansi Indonesia. Empat pilar standar akuntansi tersebut yaitu:

1. Standar Akuntansi Keuangan

2. Standar Akuntansi Pemerintahan

3. Standar Akuntansi Keuangan Syariah

4. Standar Akuntansi Keuangan Entitas Tanpa Akuntabilitas Publik atau biasa disebut dengan SAK ETAP

\subsection{Standar Akuntansi Keuangan Entitas Tanpa Akuntabilitas Publik (SAK-ETAP)}

Standar Akuntansi Keuangan untuk Entitas Tanpa Akuntabilitas Publik (SAK ETAP) dimaksudkan untuk digunakan entitas tanpa akuntabilitas publik. Entitas tanpa akuntabilitas publik adalah entitas yang:

1. Tidak memiliki akuntabilitas publik yang signifikan; dan

2. Menerbitkan laporan keuangan untuk tujuan umum (General Purpose Financial Statement) bagi pengguna eksternal. Contoh pengguna eksternal adalah pemilik yang tidak terlibat langsung dalam pengelolaan usaha, kreditur, dan lembaga pemeringkat kredit.

Suatu entitas dikatakan memiliki akuntabilitas publik signifikan jika:

1. Entitas telah mengajukan pernyataan pendaftaran, atau dalam proses pengajuan pernyataan pendaftaran, pada otoritas pasar modal atau regulator lain untuk tujuan penerbitan efek di pasar modal; atau

2. Entitas menguasai aset dalam kapasitas sebagai fidusia untuk sekelompok besar masyarakat, seperti bank, entitas asuransi, pialang dan atau pedagang efek, dana pensiun, reksa dana, dan bank investasi.

Dari pernyataan diatas, jelas mengandung makna bahwa entitas kecil dan menengah yang dimaksud oleh SAK ETAP adalah entitas kecil menengah non- listed atau entitas yang tidak masuk dalam bursa saham. Artinya ada dua standar akuntansi yang berbeda yang dijadikan acuan dalam penyusunan dan pelaporan keuangan. Ini berarti juga akan ada standar pengukuran dan 
pengungkapan yang berbeda dari masing-masing standar akuntansi tersebut. Di satu sisi ada SAK ETAP yang khusus ditujukan untuk entitas kecil menengah yang non-listed, di sisi lain ada SAK umum, dalam hal ini PSAK yang ditujukan untuk entitas lainnya, termasuk entitas kecil menengah jika entitas tersebut termasuk listed company. Laporan keuangan yang dihasilkan oleh suatu entitas nantinya harus menyebutkan bahwa laporan keuangan tersebut telah dinyatakan sesuai dengan standar akuntansi yang digunakan, apakah SAK ETAP atau PSAK. SAK ETAP diterapkan untuk penyusunan laporan keuangan yang dimulai pada atau setelah 1 Januari 2011. Penerapan dini diperkenankan. Jika SAK ETAP diterapkan dini, maka entitas harus menerapkan SAK ETAP untuk penyusunan laporan keuangan yang dimulai pada atau setelah 1 Januari 2010 (SAK ETAP 2009:166).

\subsection{Peran Akuntansi Bagi UKM}

Informasi akuntansi mempunyai peranan penting untuk mencapai keberhasilan usaha, termasuk bagi usaha kecil (Magginson et al. 2000). Informasi akuntansi dapat menjadi dasar yang andal bagi pengambilan keputusan ekonomis dalam pengelolaan usaha kecil, antara lain keputusan pengembangan pasar, penetapan harga dan lain-lain. Penyediaan informasi akuntansi bagi usaha kecil juga diperlukan khususnya untuk akses subsidi pemerintah dan akses tambahan modal bagi usaha kecil dari kreditur (Bank). Kewajiban penyelenggaraan akuntansi bagi usaha kecil sebenarnya telah tersirat dalam Undang-Undang Usaha Kecil No. 9 Tahun 1995 dan Undang-Undang Perpajakan. Pemerintah maupun komunitas akuntansi telah menegaskan pentingnya pencatatan dan penyelenggaraan akuntansi bagi usaha kecil. Adanya SAK ETAP merupakan cerminan upaya untuk mempermudah UKM dalam menyusun laporan keuangan. Hal yang baru, tentu akan menimbulkan pro dan kontra, dari situ peneliti ingin mengetahui bagaimana pengusaha UKM dalam menyikapi hal tersebut, tetap membuat laporan keuangan yang sederhana atau beralih pada laporan keuangan sesuai dengan SAK ETAP. 


\subsection{Karakteristik Kualitatif Informasi dalam Laporan Keuangan}

Tujuan dari laporan keuangan SAK ETAP itu sendiri adalah menyediakan informasi mengenai posisi keuangan, kinerja, dan laporan arus kas suatu entitas yang bermanfaat bagi sejumlah besar pengguna dalam pengambilan keputusan ekonomi oleh siapapun yang tidak dalam posisi dapat meminta laporan keuangan khusus untuk memenuhi informasi tertentu. Dalam memenuhi tujuannya, laporan keuangan juga menunjukkan apa yang telah dilakukan manajemen (stewardship) atau pertanggungjawaban manajemen atas sumberdaya yang dipercayakan kepadanya.

Menurut Soemarso (2004) Salah satu ciri khas yang membuat informasi dalam laporan keuangan berguna bagi penggunanya adalah karakteristik kualitatif, yaitu:

1. Dapat dipahami (Understandability)

2. Relevan (Relevance)

3. Materialitas (Materiality)

4. Keandalan (Reliability)

5. Substansi mengungguli bentuk (Subtance Over Form)

6. Pertimbangan Sehat (Prudence)

7. Kelengkapan (Completeness)

8. Dapat dibandingkan (Comparability)

9. Tepat waktu (Timeliness)

10. Keseimbangan antara biaya dan manfaat (Balance Between Benefit And Cost).

\subsection{Penyajian Laporan Keuangan}

Penyajian laporan keuangan dalam SAK ETAP tidak berbeda dengan sebagaimana yang diatur dalam PSAK 1: Penyajian laporan keuangan, dimana secara substansi pengaturan tersebut merupakan ringkasan dari PSAK yang juga mencakup pengaturan mengenai komponen laporan keuangan. Perbedaan yang paling mendasar adalah, dalam SAK ETAP, entitas yang menggunakan standar ini harus mengungkapkan pernyataan bahwa entitas patuh secara keseluruhan terhadap SAK ETAP ini dalam catatan atas laporan 
keuangannya. Hal lain terkait dengan pengaturan mengenai penyajan laporan keuangan ini adalah kelangsungan usaha, frekuensi pelaporan, konsistensi penyajian, informasi komparatif, materialitas, agregasi dan komponen lengkap laporan keuangan. Posisi dan kinerja keuangan yang ada dalam SAK ETAP secara umum tidak berbeda dengan yang ada dalam PSAK, yaitu aset, kewajiban, ekuitas, penghasilan dan beban. Dalam SAK ETAP, ada beberapa perbedaan yang signifikan dengan PSAK yaitu :

1. Tidak diperkenankannya adanya "pos luar biasa"

2. Diperkenankannya untuk menggabungkan laporan laba rugi dan laporan perubahan jika memenuhi kondisi tertentu, yaitu perubahan ekuitas yang hanya berasal dari :

- Laba Rugi periode berjalan

- Pembayaran dividen

- Koreksi kesalahan periode sebelumnya

- Perubahan kebijakan akuntansi

Adanya pengungkapan dalam catatan atas laporan keuangan mengenai judgement ketidakpastian dan persyaratan modal. Adapun perbedaan mendasar antara Standar Akuntansi Keuangan (PSAK) dengan Standar Akuntansi Keuangan Entitas Tanpa Akuntabilitas Publik (SAK ETAP), menurut Pricewaterhouse Coopers yaitu:

Perbedaan PSAK dengan SAK ETAP

\begin{tabular}{|c|c|c|c|}
\hline No & Perbedaan & PSAK & SAK ETAP \\
\hline 1 & $\begin{array}{l}\text { Metode yang } \\
\text { digunakan untuk } \\
\text { laporan arus kas dari } \\
\text { aktivitas operasi }\end{array}$ & $\begin{array}{l}\text { Menggunakan metode } \\
\text { langsung dan tidak } \\
\text { langsung }\end{array}$ & $\begin{array}{l}\text { Hanya menggunakan } \\
\text { metode tidak langsung }\end{array}$ \\
\hline 2 & $\begin{array}{l}\text { Metode tingkat suku } \\
\text { bunga }\end{array}$ & $\begin{array}{l}\text { Wajib bagi investasi } \\
\text { diukur pada biaya } \\
\text { amortisasi }\end{array}$ & $\begin{array}{lr}\text { Tidak secara eksplisit } \\
\text { mewajibkan bagi investasi } \\
\text { diukur pada biaya } \\
\text { amortisasi }\end{array}$ \\
\hline 3 & $\begin{array}{l}\text { Penggabungan usaha } \\
\text { dan goodwiil }\end{array}$ & $\begin{array}{l}\text { Menunjukkan } \\
\text { penggabungan } \\
\text { dan goodwiil } \\
\end{array}$ & $\begin{array}{l}\text { Tidak menunjukkan } \\
\text { penggabungan usaha dan } \\
\text { goodwiil }\end{array}$ \\
\hline 4 & $\begin{array}{l}\text { Investasi pada } \\
\text { perusahaan cabang }\end{array}$ & $\begin{array}{lr}\text { Laporan } & \text { keuangan } \\
\text { konsolidasi } & \text { bagi } \\
\text { cabangnya } & \\
\end{array}$ & $\begin{array}{l}\text { Menggunakan } \\
\text { ekuitas untuk } \\
\text { investasinya }\end{array}$ \\
\hline
\end{tabular}




\begin{tabular}{|c|c|c|c|}
\hline 5 & $\begin{array}{l}\text { Investasi } \\
\text { asosiasi }\end{array}$ & $\begin{array}{l}\text { Menggunakan metode } \\
\text { ekuitas }\end{array}$ & $\begin{array}{l}\text { Menggunakan } \\
\text { biaya }\end{array}$ \\
\hline 6 & $\begin{array}{l}\text { Pengukuran } \\
\text { property, plant and } \\
\text { equipment }\end{array}$ & \begin{tabular}{lr}
\multicolumn{2}{l}{ Menggunakan } \\
perolehan atau niaya \\
wajar
\end{tabular} & $\begin{array}{l}\text { Menggunakan } \\
\text { perolehan }\end{array}$ \\
\hline 7 & $\begin{array}{l}\text { Pendekatan metode } \\
\text { penyusutan untuk } \\
\text { property, plant and } \\
\text { equipment }\end{array}$ & $\begin{array}{lr}\text { Setiap } & \text { komponen } \\
\text { property, plant } & \text { and } \\
\text { equipment } & \text { harus } \\
\text { didepresiasi } & \text { secara } \\
\text { terpisah } & \\
\end{array}$ & $\begin{array}{l}\text { Setiap komponen property, } \\
\text { plant and equipment tidak } \\
\text { diwajibkan didepresiasi } \\
\text { secara terpisah }\end{array}$ \\
\hline 8 & Prol & $\begin{array}{l}\text { Menggunakan biaya } \\
\text { perolehan atau nilai } \\
\text { wajar }\end{array}$ & $\begin{array}{l}\text { Menggunakan } \\
\text { perolehan }\end{array}$ \\
\hline 9 & $\begin{array}{l}\text { Aset tak berwujud- } \\
\text { biaya pengembangan }\end{array}$ & 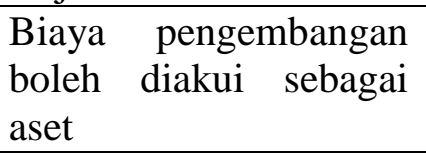 & $\begin{array}{l}\text { Biaya pengembangan } \\
\text { diakui sebagai biaya pada } \\
\text { saat terjadinya }\end{array}$ \\
\hline 10 & Pajak pe & $\begin{array}{l}\text { Meliputi periode } \\
\text { berjalan dan pajak yang } \\
\text { ditangguhkan }\end{array}$ & $\begin{array}{l}\text { Hanya pada periode } \\
\text { berjalan }\end{array}$ \\
\hline 11 & $\begin{array}{l}\text { Pengukuran imbalan } \\
\text { kerja }\end{array}$ & $\begin{array}{lr}\text { Wajib } & \text { menggunakan } \\
\text { metode } & \text { penilaian } \\
\text { aktuaria } & \\
\end{array}$ & $\begin{array}{l}\text { Boleh menggunakan } \\
\text { metode penilaian aktuaria } \\
\text { jika entitas mampu }\end{array}$ \\
\hline
\end{tabular}

Sumber : www.pwc.com

\subsection{Kerangka Penelitian}

Berdasarkan uraian diatas, maka keterkaitan variabel persepsi pengusaha kecil dan menengah tentang SAK ETAP dan variabel penggunaan SAK ETAP dapat digambarkan sebagai berikut :

Gambar 2.1

Kerangka Penelitian

\begin{tabular}{|c|}
\hline $\begin{array}{c}\text { Persepsi Pengusaha Kecil } \\
\text { dan Menengah (X) }\end{array}$ \\
\hline - Sikap \\
- Kebiasaan \\
- Kemauan \\
(Robbins, 2003) \\
\hline
\end{tabular}

\section{$\operatorname{SAK} \operatorname{ETAP}(\mathrm{Y})$}

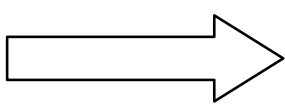

- Akuntabilitas

- Tujuan

- Karakteristik Kelengkapan Informasi 


\subsection{Hipotesis}

Berdasarkan permasalahan, tinjauan teroritis dan kerangka peneletian diatas, maka hipotesis yang diajukan adalah: persepsi pengusaha kecil dan menengah tentang SAK ETAP berpengaruh positif terhadap penggunaan SAK ETAP.

\section{METODELOGI PENELITIAN}

\subsection{Obyek Penelitian}

Pada penelitian ini penulis melakukan penelitian terhadap persepsi usaha kecil dan menengah tentang penggunaan SAK-ETAP yang terdapat di Kota Bandar Lampung. Dipilihnya lokasi ini karena Kota Bandar Lampung mempunyai pontensi besar dalam perkembangan industri di Provinsi Lampung.

\subsection{Pengumpulan Data}

Pengumpulan data-data pada penelitian ini melalui :

\section{Penelitian Kepustakaan (Library Research)}

Penelitian ini untuk mendapatkan data yang bersifat teoritis, mengenai halhal yang berkaitan dengan pokok pembahasan, dan dilakukan dengan cara membaca bebagai literatur-literatur dan sumber pustaka lainnya, yang berkaitan dengan penelitian.

\section{Penelitian Lapangan (Field Research)}

Penelitian ini dilakukan dengan cara kunjungan langsung objek penelitian. Adapun teknik pengumpualan data melalui :

a) Dokumentasi yaitu pengumpulan data yang dilakukan dengan mencatat dokumen dan arsip yang ada pada objek penelitian yang ada hubungannya dengan permasalahan yang ingin diteliti.

b) Kuisioner yaitu pengumpulan data yang dilakukan dengan cara menyebarkan daftar pertanyaan yang sudah tersedia alternatif jawaban yang berhubungan dengan penelitian. 


\section{Sumber Data}

Data dan informasi yang diperlukan dalam penelitian ini berdasarkan dari 2 sumber yaitu :

a. Data primer yaitu data yang diperoleh secara langsung melalui kuesioner,

b. Data sekunder yaitu data yang diperoleh dari studi kepustakaan dan dokumentasi dengan cara berhubungan dengan permasalahan dalam penelitian ini.

\subsection{Operasional dan Pengukuran Variabel}

Penelitian ini terdiri dari dua variabel, yakni variabel independent dan variabel dependent. Adapun yang menjadi variabel independent adalah persepsi pengusaha kecil dan menengah, yang disimbulkan dengan (X). Sedangkan yang menjadi variabel dependent adalah penggunaan SAK ETAP, yang disimbulkan dengan (Y). Definisi operasional dari masing-masing variabel yang digunakan dalam penelitian ini sebagai berikut:

Persepsi adalah proses dengan mana seseorang memilih, berusaha, dan menginterpretasikan rangsangan ke dalam suatu gambaran yang terpadu dan penuh arti. Adapun pengukuran persepsi menurut Thoha (2003) melalui: sikap, kebiasaan dan kemauan. SAK ETAP adalah standar akuntansi yang diperuntukkan bagi entitas yang tidak listed di pasar bursa dalam rangka memudahkan entitas untuk mengetahui kinerja keuangannya. Adapun pengukuran SAK ETAP melalui: akuntabilitas, tujuan, dan karakteristik kelengkapan informasi.

Pengukuran atas variabel-variabel tersebut dilakukan dengan menggunakan skala Likert yaitu suatu skala untuk mengukur sikap atau perilaku, persepsi, dan gejala-gejala dari suatu objek penelitian yang diamati dengan menggunakan instrumen daftar pertanyaan (kuesioner). Untuk kuesioner persepsi pengusaha kecil dan menengah dan penggunaan SAK ETAP diberikan nilai atau skor dengan interval sebagai berikut:

$\begin{array}{ll}\text { SS } & =\text { Sangat Setuju, 5 } \\ \text { S } & =\text { Setuju, } 4 \\ \text { CS } & =\text { Cukup Setuju, } 3 \\ \text { TS } & =\text { Tidak Setuju, } 2\end{array}$




\subsection{Populasi dan Sampel}

Adapun yang menjadi populasi dari penelitian ini adalah pengusaha kecil menengah di Kota Bandar Lampung yang berjumlah 362 usaha kecil menengah. (BPS Propinsi Lampung, 2012). Pengambilan sampel ditentukan berdasarkan teknik Suharsimi Arikonto (2000) yaitu apabila data lebih dari 100 maka jumlah sampel yang digunakan adalah $10 \%$ sampai $20 \%$ jika tingkat kesalahan besar dan 20\% sampai 25\% jika tingkat kesalahan kecil. Maka berdasarkan rumus tersebut, sampel yang diambil adalah 20\% x $362=72,4$ dibulatkan 72. Dengan demikian jumlah sampel yang diambil dalam penelitian ini berjumlah 72 sampel penelitian.

\section{Metode Analisis Data}

Metode Analisis yang digunakan dalam penelitian ini, yaitu :

\section{Analisis Kualitatif}

M. Singarimbun dan Sofian Efendi (1987:111) mengemukakan bahwa analisis kualitatif merupakan suatu analisis data yang tidak memerlukan pengujian secara matematis dan sistematis, namun hanya bersifat penjelasan berdasarkan pendapat dan interprestasi terhadap data tanggapan responden.

\section{Analisis Kuantitatif}

Analisis kuantitatif merupakan suatu analisis yang memerlukan pengujian secara matematis dan sistematis (M. Singarimbun dan Sofian Efendi, 1987:111). Adapun alat analisis yang digunakan sebagai berikut:

\section{Uji Validitas dan Reliabilits}

Uji validitas (uji kesahihan) adalah suatu alat yang digunakan untuk mengukur sah/valid tidaknya suatu kuesioner. Dikatakan valid, bila besarnya nilai $\mathrm{r}$ hitung $\geq \mathrm{r}$ tabel. Uji reliabilitas adalah alat uji untuk mengukur kuesioner yang merupakan indikator dari variabel. Dikatakan reliabel, bila besarnya nilai Cronbach Alpha melebihi angka 0,60. 


\section{Regresi Linier Sederhana}

Untuk mengetahui pengaruh persepsi UKM terhadap penggunaan SAK ETAP di Kota Bandar Lampung, maka digunakan rumus regresi linier sederhana dengan rumus sebagai berikut (Supranto, 2002:50 - 51) :

$\mathbf{Y}=\mathbf{a}+\mathbf{b X}+\mathbf{e t}$

$$
\begin{array}{ll}
\text { Dimana: } & \mathrm{Y} \\
\mathrm{a} & =\text { Penggunaan SAK ETAP } \\
\mathrm{b} & =\text { Koefisien Regresi } \\
\mathrm{X} & =\text { Persepsi Pengusaha Kecil dan Menengah } \\
\text { et } & =\text { Error Term }
\end{array}
$$

\section{HASIL DAN PEMBAHASAN}

\subsection{Analisis Kualitatif}

\section{Gambaran Umum Responden}

Karakteristik Responden Berdasarkan Jenis Kelamin

\begin{tabular}{|l|c|c|c|}
\hline Jenis Kelamin & Kode & Frekuensi & Persentase (\%) \\
\hline Laki- laki & 1 & 40 & 71,43 \\
\hline Perempuan & 2 & 16 & 28,57 \\
\hline Jumlah & & $\mathbf{5 6}$ & $\mathbf{1 0 0}$ \\
\hline
\end{tabular}

Sumber: Data Diolah, 2013

Karakteristik Responden Berdasarkan Usia

\begin{tabular}{|l|c|c|c|}
\hline Usia & Kode & Frekuensi & Persentase (\%) \\
\hline $25-35$ & 1 & 25 & 44,64 \\
\hline $36-45$ & 2 & 22 & 39,28 \\
\hline $46-55$ & 3 & 9 & 16,07 \\
\hline Jumlah & $\mathbf{5 6}$ & $\mathbf{1 0 0}$ \\
\hline
\end{tabular}

Sumber: Data Diolah, 2013 
Karakteristik Responden Berdasarkan Tingkat Pendidikan

\begin{tabular}{|l|c|c|c|}
\hline Pendidikan & Kode & Frekuensi & Persentase (\%) \\
\hline S2 & 1 & 0 & 0 \\
\hline S1 & 2 & 11 & 19,64 \\
\hline D3/SMA & 3 & 45 & 80,36 \\
\hline Jumlah & & $\mathbf{5 6}$ & $\mathbf{1 0 0}$ \\
\hline
\end{tabular}

Sumber: Data Diolah, 2013

\subsection{Tanggapan Responden Tentang Persepsi Pengusaha Kecil dan Menengah Mengenai SAK ETAP}

Untuk mengukur persepsi pengusaha kecil dan menengah mengenai SAK ETAP dipergunakan instrument atau pertanyaan sebanyak 10 pertanyaan yang mewakili 3 indikator yaitu: sikap, kebiasaan dan kemauan, dimana setiap butir pertanyaan memiliki rentang nilai 1 sampai dengan 5. Berdasarkan hasil jawaban responden atas kuesioner tentang persepsi pengusaha kecil \& menengah mengenai SAK ETAP di Kota Bandar Lampung diperoleh rekapitulasi total skor dan kriteria jawaban sebagai berikut:

Rekapitulasi Total Skor Per Item Pertanyaan dan Kriteria Jawaban atas Persepsi

Pengusaha Kecil dan Menengah Mengenai SAK ETAP (X)

\begin{tabular}{|l|l|l|l|l|l|}
\hline No & Item Pertanyaan & $\begin{array}{l}\text { Skor } \\
\text { Harapan }\end{array}$ & $\begin{array}{l}\text { Skor } \\
\text { Riil }\end{array}$ & $\begin{array}{l}\text { Persentase } \\
(\boldsymbol{\%})\end{array}$ & Kriteria \\
\hline 1 & $\begin{array}{l}\text { Sikap Bapak/Ibu selaku pengusaha } \\
\text { kecil terhadap SAK ETAP, apakah } \\
\text { telah memudahkan dalam mengelola } \\
\text { kegiatan usaha. }\end{array}$ & 199 & 71,07 & Baik \\
\hline 2 & $\begin{array}{l}\text { Dengan SAK ETAP, apakah } \\
\text { akuntabilitas memudahkan } \\
\text { Bapak/Ibu mengetahui } \\
\text { perkembangan dari kegiatan usaha. }\end{array}$ & 280 & 212 & 75,71 & Baik \\
\hline 3 & $\begin{array}{l}\text { Dari aspek kepentingan publik, SAK } \\
\text { ETAP telah signifikan mendukung } \\
\text { kepentingan usaha anda. }\end{array}$ & 280 & 206 & 73,57 & Baik \\
\hline 4 & $\begin{array}{l}\text { SAK ETAP meningkatkan } \\
\text { pengelolaan usaha yang efisien dan } \\
\text { efektif. }\end{array}$ & 280 & 187 & 66,78 & Baik \\
\hline 5 & $\begin{array}{l}\text { SAK ETAP lebih memudahkan } \\
\text { dalam penerbitan laporan keuangan }\end{array}$ & 280 & 210 & 75,00 & Baik \\
\hline 6 & $\begin{array}{l}\text { Dengan mengaplikasikan SAK } \\
\text { ETAP, apakah dapat dipahami oleh } \\
\text { semua pihak terkait. }\end{array}$ & 280 & 205 & 73,21 & Baik \\
\hline
\end{tabular}




\begin{tabular}{|l|l|l|l|l|l|}
\hline 7 & $\begin{array}{l}\text { SAK ETAP memudahkan bagi saya } \\
\text { (pengusaha) untuk mengevaluasi, } \\
\text { pengendalian atau pengawasan dan } \\
\text { pelaporan informasi akuntansi. }\end{array}$ & 280 & 75,35 & Baik \\
\hline 8 & $\begin{array}{l}\text { SAK ETAP berperan sebagai alat } \\
\text { yang dipergunakan untuk } \\
\text { pengumpulan, pengolahan dan } \\
\text { penyajian informasi akuntansi. }\end{array}$ & 280 & 202 & 72,14 & Baik \\
\hline 9 & $\begin{array}{l}\text { SAK ETAP dapat dibandingkan } \\
\text { untuk membantu memberikan } \\
\text { gambaran kondisi lingkungan } \\
\text { internal dan eksternal perusahaan. }\end{array}$ & 280 & 202 & 72,14 & Baik \\
\hline 10 & $\begin{array}{l}\text { SAK ETAP sangat membantu untuk } \\
\text { pengambilan keputusan bagi saya } \\
\text { pengusaha) mengantisipasi situasi } \\
\text { ekonomi. }\end{array}$ & 280 & 188 & 67,14 & Baik \\
\hline Rata-Rata & 280 & 202,2 & 72,21 & Baik \\
\hline
\end{tabular}

Sumber: Data Diolah, 2013

Keterangan:

$\begin{array}{rlll}0,00 \%-20,00 \% & : & & \text { Sangat Tidak Baik ((STB) } \\ 20,01 \%-40,00 \% & : & \text { Kurang Baik (KB) } \\ 40,01 \%-60,00 \% & : & \text { Sedang (S) } \\ 60,01 \%-80,00 \% & : & \text { Baik (B) } \\ 80,01 \%-100,00 \% & : & \text { Sangat Baik (SB) }\end{array}$

\subsection{Tanggapan Responden atas Penggunaan SAK ETAP (Y)}

Untuk mengukur penggunaan SAK ETAP ini dipergunakan instrument sebanyak 10 pertanyaan yang mewakili 3 indikator yaitu: akuntabilitas, tujuan dan karakteristik kelengkapan informasi, dimana setiap butir pertanyaan memiliki rentang nilai 1 sampai dengan 5. Berdasarkan hasil jawaban responden atas kuesioner tentang penggunaan SAK ETAP diperoleh rekapitulasi total skor dan kriteria jawaban sebagai berikut: 
Rekapitulasi Total Skor Per Item Pertanyaan dan Kriteria Jawaban atas

Penggunaan SAK ETAP (Y)

\begin{tabular}{|c|c|c|c|c|c|}
\hline No & Indikator & $\begin{array}{l}\text { Skor } \\
\text { Harapan }\end{array}$ & Skor Riil & $\begin{array}{l}\text { Persentase } \\
\%\end{array}$ & Kriteria \\
\hline 1 & $\begin{array}{l}\text { Sebagai pengusaha apakah } \\
\text { Bapak/Ibu memahami } \\
\text { akuntansi } \\
\text { menjalankan usaha. }\end{array}$ & 280 & 198 & 70,71 & Baik \\
\hline 2 & $\begin{array}{l}\text { Dalam kaitanya dengan } \\
\text { pengetahuan akuntansi } \\
\text { apakah Bapak/Ibu telah } \\
\text { melaksanakannya. }\end{array}$ & 280 & 196 & 70,00 & Baik \\
\hline 3 & $\begin{array}{l}\text { Dalam pemrosesan data } \\
\text { akuntansi, apakah semua } \\
\text { transaksi dicatat ke dalam } \\
\text { buku besar secara continue. }\end{array}$ & 280 & 204 & 72,85 & Baik \\
\hline 4 & $\begin{array}{l}\text { Pencatatan semua transaksi } \\
\text { dari kegiatan perusahaan } \\
\text { mengikuti kententuan } \\
\text { akuntansi yang benar } \\
\text { seperti jurnal, buku besar } \\
\text { dan akun-akun akuntansi. }\end{array}$ & 280 & 185 & 66,07 & Baik \\
\hline 5 & $\begin{array}{lc}\text { Apakah } & \text { informasi } \\
\text { akuntansi keuangan yang } \\
\text { dihasilkan secara manual } \\
\text { sesuai dengan SAK ETAP }\end{array}$ & 280 & 179 & 63,92 & Baik \\
\hline 6 & $\begin{array}{l}\text { Apakah informasi } \\
\text { akuntansi yang diterapkan } \\
\text { dengan komputerisasi telah } \\
\text { sesuai SAK ETAP }\end{array}$ & 280 & 173 & 61,78 & Baik \\
\hline 7 & $\begin{array}{l}\text { Dalam membuat catatan } \\
\text { atau pemrosesan data } \\
\text { akutansi dilakukan oleh } \\
\text { pegawai yang memiliki } \\
\text { latar belakang akuntansi. }\end{array}$ & 280 & 199 & 71,42 & Baik \\
\hline 8 & $\begin{array}{l}\text { Tenaga atau staf akuntansi } \\
\text { yang melakukan } \\
\text { pengolahan data akuntansi } \\
\text { memahami SAK ETAP }\end{array}$ & 280 & 188 & 71,07 & Baik \\
\hline 9 & $\begin{array}{l}\text { Dalam mengelola kegiatan } \\
\text { usaha para karyawan telah } \\
\text { berpengalaman kurang dari } \\
\text { lima tahun. }\end{array}$ & 280 & 165 & 58,92 & $\begin{array}{l}\text { Cukup } \\
\text { Baik }\end{array}$ \\
\hline 10 & $\begin{array}{l}\text { Apakah dalam mengelola } \\
\text { kegiatan usaha para } \\
\text { karyawan } \\
\text { berpengalaman lebih dari } \\
\text { lima tahun sampai sepuluh } \\
\text { tahun. }\end{array}$ & 280 & 198 & 70,71 & Baik \\
\hline & Rata-Rata & 280 & 188,2 & 67,21 & Baik \\
\hline
\end{tabular}

Sumber: Data Diolah, 2013 


\subsection{Analisis Kuantitatif}

\section{Uji Validitas dan Reliabilitas}

Dalam uji validitas data digunakan Pearson's Product Moment, sedangkan untuk uji reliabilitas data menggunakan Cronbach's Alpha. Berdasarkan hasil pengolahan data dengan Program SPSS 19.0 untuk uji validitas data diperoleh nilai koefisien korelasi Pearson's Product Moment untuk masing-masing item pertanyaan dari masing-masing variabel adalah sebagai berikut :

Hasil Uji Validitas Persepsi Pengusaha Kecil \& Menengah (X)

\begin{tabular}{|c|c|c|c|c|}
\hline Pertanyaan & $\mathrm{r}_{\text {hitung }}$ & $\mathrm{r}_{\text {tabel }}$ & Kondisi & Keterangan \\
\hline 1 & 0,712 & 0,263 & $\mathrm{r}$ hitung $>\mathrm{r}$ tabel & Valid \\
\hline 2 & 0,742 & 0,263 & $\mathrm{r}$ hitung $>\mathrm{r}$ tabel & Valid \\
\hline 3 & 0,720 & 0,263 & $\mathrm{r}$ hitung $>\mathrm{r}$ tabel & Valid \\
\hline 4 & 0,735 & 0,263 & $\mathrm{r}$ hitung $>\mathrm{r}$ tabel & Valid \\
\hline 5 & 0,793 & 0,263 & $\mathrm{r}$ hitung $>\mathrm{r}$ tabel & Valid \\
\hline 6 & 0,771 & 0,263 & $\mathrm{r}$ hitung $>\mathrm{r}$ tabel & Valid \\
\hline 7 & 0,725 & 0,263 & $\mathrm{r}$ hitung $>\mathrm{r}$ tabel & Valid \\
\hline 8 & 0,768 & 0,263 & $\mathrm{r}$ hitung $>\mathrm{r}$ tabel & Valid \\
\hline 9 & 0,825 & 0,263 & $\mathrm{r}$ hitung $>\mathrm{r}$ tabel & Valid \\
\hline 10 & 0,742 & 0,263 & $\mathrm{r}$ hitung $>\mathrm{r}$ tabel & Valid \\
\hline
\end{tabular}

Sumber: Data diolah, 2013

Hasil Uji Validitas Penggunaan SAK ETAP (Y)

\begin{tabular}{|c|c|c|c|c|}
\hline Pertanyaan & $\mathrm{r}_{\text {hitung }}$ & $\mathrm{r}_{\text {tabel }}$ & Kondisi & Keterangan \\
\hline 1 & 0,583 & 0,263 & $\mathrm{r}$ hitung $>\mathrm{r}$ tabel & Valid \\
\hline 2 & 0,583 & 0,263 & $\mathrm{r}$ hitung $>\mathrm{r}$ tabel & Valid \\
\hline 3 & 0,476 & 0,263 & $\mathrm{r}$ hitung $>\mathrm{r}$ tabel & Valid \\
\hline 4 & 0,536 & 0,263 & $\mathrm{r}$ hitung $>\mathrm{r}$ tabel & Valid \\
\hline 5 & 0,600 & 0,263 & $\mathrm{r}$ hitung $>\mathrm{r}$ tabel & Valid \\
\hline 6 & 0,562 & 0,263 & $\mathrm{r}$ hitung $>\mathrm{r}$ tabel & Valid \\
\hline 7 & 0,715 & 0,263 & $\mathrm{r}$ hitung $>\mathrm{r}$ tabel & Valid \\
\hline 8 & 0,630 & 0,263 & $\mathrm{r}$ hitung $>\mathrm{r}$ tabel & Valid \\
\hline 9 & 0,264 & 0,263 & $\mathrm{r}$ hitung $<\mathrm{r}$ tabel & Valid \\
\hline 10 & 0,612 & 0,263 & $\mathrm{r}$ hitung $>\mathrm{r}$ tabel & Valid \\
\hline
\end{tabular}

Sumber: Data diolah, 2013

Dikatakan valid karena nilai koefisien korelasi Pearson Correlation $\left(\mathrm{r}_{\text {hitung }}\right)$ lebih besar dari $r_{\text {tabel }}$ yaitu 0,263. 
Hasil Uji Reliabilitas Variabel Penelitian

\begin{tabular}{|l|l|l|l|l|l|}
\hline No & Variabel Penelitian & $\begin{array}{l}\text { N of } \\
\text { Items }\end{array}$ & $\begin{array}{l}\text { Cronbach's } \\
\text { Alpha }\end{array}$ & Kondisi & Keterangan \\
\hline 1 & Persepsi Pengusaha (X) & 10 & 0,914 & $>0,60$ & Reliabel \\
\hline 2 & Penggunaan SAK ETAP (Y) & 10 & 0,743 & $>0,60$ & Reliabel \\
\hline
\end{tabular}

Sumber : Data Diolah, 2013

Berdasarkan hasil uji reliabilitas diatas, tampak nilai koefisiensi Cronbach's Alpha untuk semua variabel penelitian, yakni persepsi pengusaha kecil dan menengah mengenai SAK ETAP (X) dan penggunaan SAK ETAP (Y) menunjukan nilai koefisien Cronbach's Alpha lebih besar dari nilai batas minimal 0,60 (Nunnaly, 1967 dalam Ghozali, 2006) sehingga semua variabel penelitian dapat dikatakan reliabel.

\subsection{Analisis Regresi Linear Sederhana}

Untuk mengetahui pengaruh persepsi pengusaha kecil dan menengah mengenai SAK ETAP (X) terhadap penggunaan SAK ETAP (Y) di Kota Bandar Lampung digunakan regresi linear sederhana.

Berdasarkan hasil pengolahan data dengan program SPSS 19.0 diperoleh nilai koefisien regresi linear sederhana sebagai berikut :

Coofficients Regresi Linier Sederhana

Coefficients $^{\mathrm{a}}$

\begin{tabular}{|c|c|c|c|c|c|c|}
\hline \multirow{2}{*}{\multicolumn{2}{|c|}{ Model }} & \multicolumn{2}{|c|}{ Unstandardized Coefficients } & $\begin{array}{l}\text { Standardized } \\
\text { Coefficients }\end{array}$ & \multirow[b]{2}{*}{$\mathrm{t}$} & \multirow[b]{2}{*}{ Sig. } \\
\hline & & B & Std. Error & Beta & & \\
\hline & (Constant) & 22,760 & 3,097 & & 7,349 &, 000 \\
\hline & PERSEPSI &, 300 & ,084 & 437 & 3,567 & ,001 \\
\hline
\end{tabular}

a. Dependent Variable: PENGGUNAAN SAK ETAP

Sumber : Data Diolah, 2013

Berdasarkan pada tabel diatas diperoleh persamaan regresi linier sederhana sebagai berikut:

$\mathbf{Y}=\mathbf{2 2 , 7 6 0 + 0 , 3 0 0 X}$ Persamaan tersebut mengandung arti bahwa variabel persepsi pengusaha kecil dan menengah tentang SAK ETAP (X) berpengaruh positif terhadap variabel penggunaan SAK ETAP (Y) di Kota 
Bandar Lampung, sehingga setiap peningkatan yang dilakukan terhadap variabel persepsi pengusaha kecil dan menengah mengenai SAK ETAP (X) sebesar 1 unit akan meningkatkan variabel penggunaan SAK ETAP (Y) di Kota Bandar Lampung sebesar 0,300 pada konstanta 22,760.

\subsection{Uji Hipotesis}

Pengujian hipotesis dilakukan dengan menggunakan uji $t$ dengan menggunakan tingkat kepercayaan $95 \%$ atau $(\alpha=0,05)$ dan $\mathrm{df}=\mathrm{n}-\mathrm{k}-1=54$.

Adapun kriteria atau ketentuan penerimaan dan penolakan hipotesis dengan uji $t$ sebagai berikut :

Jika $\mathrm{t}_{\text {hitung }}>(\alpha 0,05) \mathrm{t}_{\text {tabel }}$, maka $\mathrm{H}_{\mathrm{o}}$ ditolak, $\mathrm{H}_{\mathrm{a}}$ diterima.

Jika $\mathrm{t}_{\text {hitung }} \leq(\alpha 0,05) \mathrm{t}_{\text {tabel }}$, maka $\mathrm{H}_{\mathrm{o}}$ diterima, $\mathrm{H}_{\mathrm{a}}$ ditolak.

Hipotesis yang diajukan dalam penelitian ini adalah :

$\mathrm{H}_{\mathrm{o}}$ : Persepsi pengusaha kecil dan menengah tentang SAK ETAP (X) tidak berpengaruh positif terhadap penggunaan SAK ETAP (Y) di Kota Bandar Lampung.

$\mathrm{H}_{\mathrm{a}}$ : Persepsi pengusaha kecil dan menengah tentang SAK ETAP (X) berpengaruh positif terhadap penggunaan SAK ETAP (Y) di Kota Bandar Lampung.

Berdasarkan hasil pengolahan data dengan program SPSS 19.0 diperoleh nilai t hitung untuk variabel persepsi pengusaha kecil dan menengah sebagai berikut :

Hasil Uji t_Persepsi Pengusaha Kecil dan Menengah

\begin{tabular}{|c|c|c|c|c|c|c|}
\hline \multicolumn{7}{|c|}{ Coefficients $^{\mathrm{a}}$} \\
\hline \multirow[b]{2}{*}{ Model } & & \multicolumn{2}{|c|}{ Unstandardized Coefficients } & $\begin{array}{l}\text { Standardized } \\
\text { Coefficients }\end{array}$ & \multirow[b]{2}{*}{$\mathrm{t}$} & \multirow[b]{2}{*}{ Sig. } \\
\hline & & $\mathrm{B}$ & Std. Error & Beta & & \\
\hline \multirow[t]{2}{*}{1} & (Constant) & 22,760 & 3,097 & & 7,349 &, 000 \\
\hline & PERSEPSI &, 300 & ,084 &, 437 & 3,567 & 001 \\
\hline
\end{tabular}

a. Dependent Variable: PENGGUNAAN SAK ETAP

Sumber : Data Diolah, 2013

Dari tabel di atas dapat dilihat nilai $t_{\text {hitung }}$ pada taraf nyata $\mathrm{df}=54$ dan $\alpha=0,05$ sebesar 3,567 signifikan pada p-value 0,001 dan nilai $t_{\text {tabel }}$ (lampiran $t$ tabel) sebesar 2,005, sehingga nilai $t_{\text {hitung }}>t_{\text {tabel }}$. Dengan demikian Ha diterima dan Ho 
ditolak. Artinya dapat dikatakan bahwa hipotesis yang menyatakan bahwa persepsi pengusaha kecil dan menengah tentang SAK ETAP (X) berpengaruh positif terhadap penggunaan SAK ETAP (Y) di Kota Bandar Lampung terbukti dan dapat diterima kebenarannya.

\subsection{Koefisien Determinasi $\left(\mathbf{R}^{2}\right)$}

Untuk mengetahui besaran kontribusi pengaruh persepsi pengusaha kecil dan menengah tentang SAK ETAP $(\mathrm{X})$ berpengaruh positif terhadap penggunaan SAK ETAP (Y) di Kota Bandar Lampung dapat diketahui melalui Koefisien Determinasi $\left(\mathrm{R}^{2}\right)$. Berdasarkan hasil pengolahan data dengan program SPSS 19.0 diperoleh nilai Koefisien Determinasi $\left(\mathrm{R}^{2}\right)$ seperti yang terlihat pada tabel berikut ini:

Koofesien Determinasi $\left(\mathrm{R}^{2}\right)$

\begin{tabular}{|l|l|l|l|l|}
\hline Model & R & R Square & $\begin{array}{l}\text { Adjusted } \\
\text { Square }\end{array}$ & $\begin{array}{l}\text { Std. Error of the } \\
\text { Estimate }\end{array}$ \\
\hline 1 &, $526^{\text {a }}$ &, 276 &, 249 & 4,205 \\
\hline
\end{tabular}
a. Predictors: (Constant), PERSEPSI
Sumber : Data Diolah, 2013

Berdasarkan tabel diatas diperoleh nilai Koefisien Determinasi $\left(\mathrm{R}^{2}\right)$ persepsi pengusaha kecil dan menengah menunjukkan nilai sebesar 0,276. Hal ini menggambarkan bahwa 27,6\% variansi perubahan penggunaan SAK ETAP (Y) di Kota Bandar Lampung disebabkan persepsi pengusaha kecil dan menengah, sedangkan sisanya sebesar 73,4\% dipengaruhi faktor-faktor lain diluar penelitian ini.

\section{KESIMPULAN DAN SARAN}

\subsection{Kesimpulan}

Berdasarkan hasil pembahasan, maka dapat disimpulkan bahwa persepsi pengusaha kecil dan menengah tentang SAK ETAP berpengaruh positif terhadap penggunaan SAK ETAP di Kota Bandar Lampung. 


\subsection{Saran}

Berdasarkan kesimpulan diatas, maka saran yang penulis ajukan dalam penelitian ini adalah: dalam penggunaan SAK ETAP, sikap, kebiasaan dan kemauan sumber daya manusia perlu ditingkatkan lebih baik lagi. Karena dengan peningkatkan sikap, kebiasaan dan kemauan sumber daya manusia dalam penggunaan SAK ETAP akan memberi dampak positif terhadap pengambilan keputusan. Peningkatan sikap, kebiasaan dan kemauan sumber daya manusia dapat dilakukan dengan pendidikan dan pelatihan yang terprogram dengan baik dan berkelanjutan.

\section{DAFTAR PUSTAKA}

Arindita, S. 2003. Hubungan antara Persepsi Kualitas Pelayanan dan Citra Bank dengan Loyalitas Nasabah. Skripsi (tidak diterbitkan). Surakarta: Fakultas Psikologi UMS.

C. Trihendradi. 2011. Analisis Statistik dengan SPSS 19. Andi, Yogyakarta.

Dewan Standar Akuntansi Keuangan. 2009. Standar Akuntansi Keuangan Entitas Tanpa Akuntabilitas Publik. Ikatan Akuntan Indonesia, Jakarta.

Holmes, S., \& Nicholls, D., (1989), Modeling The Accounting Information Requirements of Small Businesses. Accounting and Business Research, 19 (74), pp143-150.

Ikhsan, Arfa dan Muhammad Ishak. 2005. Akuntansi Keprilakuan. Salemba Empat, Jakarta.

Istijanto. 2006. Riset Sumber Daya Manusia, Cara-Cara Mendeteksi DimensiDimensi Kerja Karyawan. PT. Gramedia Pustaka Utama, Jakarta.

Jati, Hironnymus, Bala, Beatus, dan Otnil Nisnoni. 2004.“Menumbuhkan Kebiasaan Usaha Kecil Menyusun Laporan Keuangan.” Jurnal Bisnis dan Usahawan, II No. $8: 210$ - 218.

Longenecker, Justin G. 2001. Kewirausahaan Manajemen Usaha Kecil. Jakarta.

Badan Pusat Statistik Proponsi Lampung. 2012. Lampung Dalam Angka.

M. Singarimbun, Sofyan Efendi. 1987. Metode Penelitian Survey, Andi Offset, Yogyakarta. 
Megginson, W.L., M.J. Byrd, and L.C. Megginson. 2000. Small Business Management: An Entrepreneur's Guidebook. Third Ed. Irwin McGraw-Hill. Boston.

Rakhmat, Jalaluddin. 1993. Psikologi Komunikasi Edisi Revisi. PT. Remaja Rosdakarya, Bandung.

Robbins, Stephen P. 2003. Prinsip-Prinsip Perilaku Keorganisasian. Erlangga, Jakarta.

Rosyadi, I. 2001. Keunggulan Kompetitif Berkelanjutan Melalui CapabilitiesBased Competition: Memikirkan kembali tentang persaingan berbasis kemampuan. Jurnal BENEFIT, vol. 5, No. 1, Juni 2001. Surakarta: Fakultas Ekonomi Universitas Muhammadiyah Surakarta.

Soemarso. 2004. Akuntansi Suatu Pengantar Edisi Lima Revisi. Salemba Empat, Jakarta.

Subanar, Harimurti. 2001. Manajemen Usaha Kecil Edisi Pertama. BPFE, Yogyakarta.

Sugiyono. 2005. Statistik untuk Penelitian Cetakan Kesepuluh. Alfabeta,

Bandung.

Suharsimi Arikunto. 2000. Prosedur Penelitian. PT. Rineka Cipta, Jakarta.

Suhardjono. 2003. Manajemen Perkreditan UKM. UPP AMP YKPN, Yogyakarta. Suryana. 2001. Kewirausahaan. Salemba Empat, Jakarta.

Taniputera, Ivan. 2005. Psikologi Kepribadian. AR-RUZZ Media. Jogjakarta.

Tim Penyusun Kamus Pusat Pembinaan dan Pengembangan Bahasa. 1999. Kamus Besar Bahasa Indonesia Edisi Kedua, Departemen Pendidikan dan Kebudayaan. Balai Pustaka, Jakarta.

Undang-Undang No 20 Tahun 2008 Tentang Usaha Kecil dan Menengah.

Wahdini \& Suhairi. 2006. Persepsi Akuntan terhadap Overload Standar Akuntansi Keuangan (SAK) bagi UKM. Simposium Nasiaonal Akuntansi IX Padang.

Williams, Chen, \& Tearney. 1989. Accounting Standards: Overskill For Small Busines. The National Public Accountant : June pp 40-43.

Wulan dan Andi Nindita Fajar. 2009. Kemandirian Perempuan Indonesia Dalam Perekonomian Abad 21. Skripsi, Universitas Gunadarma, Jakarta. 